\title{
Bioactive compounds and antioxidant activity of crisphead lettuce (Lactuca sativa L.) of three different cultivation systems
}

\author{
Leonardo Dias NEGRÃO ${ }^{1}$, Paulo Víctor de Lima SOUSA², Ana Maria BARRADAS', \\ Amanda de Castro Amorim Serpa BRANDÃO², Marcos Antônio da Mota ARAÚJO3, \\ Regilda Saraiva dos Reis MOREIRA-ARAÚJO ${ }^{4 *}$
}

\begin{abstract}
Lettuce is a vegetable most consumed and produced on a large scale in the world, it deserves special attention for its nutritional and functional value. Cultivated in the conventional, hydroponic and organic method, it presents different characteristics in production, which may influence the composition of this vegetable. It is indisputable that regular consumption of vegetables is beneficial due to the presence of bioactive compounds with antioxidant properties that protect and promote human health. In this study, the total phenolic compound, flavonoid, and tannin contents, as well as the antioxidant activities of lettuce samples from conventional, hydroponic, and conventional cultivars were analyzed. An extract was prepared using $80 \%$ acetone. The contents of total phenolic compounds, flavonoids, and tannins were determined. The antioxidant activity was determined by the radical capture method using DPPH. It was observed that the organic cultivation system had the highest values of ash, protein, total phenolic compounds, flavonoids and antioxidant activity, followed by the hydroponic system. The organic system presented greater protein content and higher content of bioactive compounds, justifying the high antioxidant activity. Therefore, the organic farming system favors the highest concentration in the content of bioactive compounds and antioxidant activity.
\end{abstract}

Keywords: nutritional value; vegetables; Lactuca sativa L.

Practical Application: Lettuce is one of the most consumed vegetables among Brazilians and is accessible in three types of cultivation system, the study shows how the influence of the system of cultivation on its composition and mainly in the production of bioactive compounds that help in the prevention of the development of diseases. Since organic farming system has a higher content than the conventional one, and in contrast, it shows that the hydroponic system also has more benefits than the conventional one.

\section{Introduction}

The crisphead lettuce (Lactuca sativa L.) is the most consumed vegetable in Brazil, being considered a horticultural culture of great consumption (Fernandes et al., 2002). In the world it is one of the most important green leafy vegetables (Campos et al., 2019) and consumed on a large scale (Patella et al., 2019), being produced around 27 million tons per year (Food and Agriculture Organization of the United Nations, 2019). It is a vegetable that deserves special interest, not only for its food importance but also for its nutritional and functional value (Chiconato et al., 2014). Curly lettuce is a fresh vegetable consumed alone or in combination with other vegetables ready for consumption, usually consumed in mixed and fresh-cut salads. Depending on the leaf type and growing conditions, its edible leaves present high demand for nutrients (El-Nakhel et al., 2019; Oliveira et al., 2018; Patella et al., 2019).

Its cultivation has been practiced in the conventional, hydroponic and organic form, which have distinctive characteristics in the production, and can influence the properties of this vegetable. Organic cultivation defined as a production system that avoids or excludes the use pesticides, fertilisers or agrochemicals, synthetic composition fertilizers, growth regulators or other contaminants, arises as an option of production to highly agricultural Mechanized and rich in industrial inputs (Kashyap et al., 2017), which characterize conventional system. Hydroponic vegetables must necessarily receive nutrients previously dissolved in water, as they are grown outside their natural environment (soil), in plastic tubes, where water is circulated containing chemical fertilizers, and one the systems for fresh leafy green vegetables with better quality control (El-Nakhel et al., 2019).

Phenolic compounds are phytochemicals that present in vegetable foods and usually present antioxidant properties (Ketnawa et al., 2020). Among them are the flavonoids (anthocyanins, flavonoids, flavanols, flavonones, isoflavones), phenolic acids (derived from hidroxicinâmico acid by highlighting the caffeic acids, ferulic, synaptic, p-cumaric acid; and derivatives of the acid Hydroxybenzoic, highlighting the vanillic acids, syringic, Gentisic, Salicylic, ellagic, Gallic) (Shahidi et al., 1992). 
Epidemiological, clinical and in vitro studies show multiple biological effects related to the phenolic compounds of the diet, such as: antioxidant activity, antinflammatory, antimicrobial, preventing heart disease, diabetes, cancer and stroke (Souza et al., 2018). The efficacy of the antioxidant action of the bioactive compounds depends on the chemical structure and its concentration in the food. In lettuce, the content of phenolic compounds (flavonols, caffeic acids and its derivatives, carotenoids and the vitamins $\mathrm{C}$ and $\mathrm{E}$ are the most concentrated) and antioxidant action are highlighted phytochemicals in greenery is largely influenced by genetic factors, environmental conditions, production system, among others. (Ketnawa et al., 2020; Pei et al., 2020). However, few jobs aim to verify the influence of the type of cultivation in the antioxidant action of these foods.

The research of risk factors and protection for chronic diseases by telephone survey-Vigitel (Brasil, 2017), showed a change in the whole adult population studied, with regular consumption of fruits and vegetables of $35.2 \%$, being $28.8 \%$ in men and $40.7 \%$ in women, lettuce being one of the vegetables that belongs to the habit of consumption of the population in general and easily accessible, under various forms of cultivation, thus constituting an indispensable component of the salads of the Brazilians.

This study analyzed the physico-chemical composition, bioactive compounds, among these the contents of total phenolic, flavonoids and tannins, and the antioxidant activity of the lettuce from the conventional, hydroponic and organic cultivation system, the order to provide information about its nutritional and functional potential, as well as its impact on health.

\section{Materials and methods}

\subsection{Experimental protocol}

Samples of lettuce (Lactuca sativa L.) of three cultivation systems (conventional, organic and hydroponic) were collected in the retail trade of Teresina and were forwarded and stored in the laboratory of Bromatology and Food Biochemistry (LABROMBIOQ) in the Nutrition Department of the Federal University of Piauí (UFPI), under refrigeration $\left(8^{\circ} \mathrm{C}\right)$ until their analysis. The lettuces were manually scanned for removal of impurities and unhealthy lettuces. All analyses were performed in triplicate in the period from twelve months.

\subsection{Proximate composition and total energy value}

Moisture was determined until constant weight was observed after drying in an oven oat $105^{\circ} \mathrm{C}$. Ash content was determined after calcination of the samples in a muffle furnace at $550{ }^{\circ} \mathrm{C}$ up to constant mass. Protein concentration was determined using the Macro-Kjeldahl method with a conversion factor of 5.14 (for plant proteins), and lipid content was determined by intermittent hot extraction using hexane as a solvent in a Soxhlet apparatus (Association of Official Analytical Chemists, 2005). Carbohydrate content was calculated using the difference method, and the total energy value was determined according to Atwater conversion factors (Atwater \& Woods, 1896; Watt \& Merrill, 1963).

\subsection{Bioactive compounds}

\section{Extraction}

The extracts were obtained according to Rufino et al. (2010). Thus, $0.5 \mathrm{~g}$ of curly lettuce were heavy in centrifugal tubes $(50 \mathrm{~mL})$ with $8 \mathrm{~mL}$ of acetone $80 \%$ resulted in better extraction yields.

\section{Total phenols, total flavonoids and condensed tannins}

The total phenolic compounds content was determined by spectrophotometric methods; the total phenolics compounds (Singleton \& Rossi, 1965); total flavonoids (Kim et al., 2003), modified by Blasa et al. (2006); condensed tannins content (Price et al., 1978).

\subsection{Antioxidant activity by the DPPH}

The antioxidant activity of the extract was determined according to Brand-Williams et al. (1995), using, 2.2-diphenyl1-picril-Hidrazil (DPPH).

\subsection{Statistical analysis}

Data analysis was performed using the Statistical Package program for the Social Sciences (SPSS), version 17.0. The results are presented in the form of tables with their averages and their respective standard deviations. There was a difference between the averages of the centesimal compositions and the condensed tannin content in relation to the cultivation system was used the Student $\mathrm{t}$ test, while for the total phenolic compounds and antioxidant activity according to the system of Crops the test applied was Tukey, at a level of 5\% ( $\mathrm{p}<0.05)$, with the confidence level of 95\%, respectively (Hilbe \& Robinson, 2013).

\section{Results and discussion}

In the present study, the centesimal composition was analyzed for the physicochemical characterization of the crisphead lettuce (Lactuca sativa L.) in the conventional, hydroponic and organic cultivation system, as well as the Total energy value. The Table 1 demonstrates the values obtained for the content of moisture, ash, proteins, lipids, carbohydrates and Total Energy Value (VET) for the lettuce of the three cultivation systems.

According to the results obtained for moinsture, there was no statistically significant difference between the lettuce produced by the conventional, hydroponic and organic cultivation system whose values ranged from 94.74 to $95.21 \%$. For ashes only the hydroponic system showed difference between the others systems with $0.71 \%$. The protein content, a statistically significant difference was observed between the cultivation systems, in which the lettuce of the organic cultivation system was the one that obtained higher protein content with $1.86 \%$.

With regard to the lipid content (Table 1) obtained, a statistically significant difference was observed between the lettuce samples, with the lettuce of the conventional cultivation system presenting higher lipid content $(0.80 \%)$, followed by the cultivation Hydroponic (0.66\%) and organic farming (0.52\%). Among the samples of the studied lettuces, for the carbohydrate content, there was no significant difference $(\mathrm{p}<0.05)$ between 
the conventional and organic cultivation systems, in which the conventional cultivation plant presented a higher carbohydrate content of $1.97 \%$. However there was statistically significant difference to the hydroponic system, where the carbohydrate content was $2.09 \%$.

The small variations of the results can be justified by the technique of cultivation, soil, climate, fertilizer, as well as the management of the farmer that can influence the moisture content of the lettuce, since, the time of stay of the plants of lettuce in the final phase of the cultivation Influence the moisture content, which, according to Souza et al. (2019), being expected in the hydroponic cultivation a higher moisture content, since its production is grown in water.

In the hydroponic system, lettuce accumulates different ash levels according to the type of nutrient solution used in this cultivation system (Fernandes et al., 2002; Fontana et al., 2018; Souza et al., 2019). This can be explained by the influence of the nutritional solutions of the hydroponic system in the proximate composition. Justifying the difference found for the hydroponic system.

The effect of the production system on the nutritional quality of crisphead lettuce, obtained higher results for the protein, ashes and carbohydrate content of the conventional system. (Fontana et al., 2018; Gontijo et al., 2017).

Gontijo et al. (2017) verified the contents of lipids that ranged from 0.16 to $0.17 \%$, these being smaller than the results obtained in this study. The variations of results observed for the lipid content in the literature are due to the fact that the conditions of extraction of lipids of the food matrix, the methodology employed, as well as the type of solvent used in its extraction, as it may occur the extraction of Pigments interfering with their quantification.
On the other hand, one of the reasons that can affect the analysis of lipids is the difference in the concentration of chlorophyll between the types of cultivation. Due to the different soil, climatic and physiological conditions resulting or not from the three cultivation systems, they lead to variations in the levels obtained in other studies.

For the lettuce of the conventional cultivation system, it was $20.84 \mathrm{kcal}$ or $87.19 \mathrm{KJ}$. This difference can be explained due to conventional cultivation lettuce having presented higher lipid levels (Table 1), reflecting on the increase of the TEV.

However, the highest content of carbohydrates, proteins and ashes stands out in organic and hydroponic farming systems. Being very well elucidated in the literature (Fontana et al., 2018; Gontijo et al., 2017; Rodrigo-García et al., 2019; Souza et al., 2019; Zambrano-Moreno et al., 2015). In addition, there is also a difference in the concentration of bioactive compounds present in vegetables, due to the need of the plant to need more protective factors against the climate, soil, pests and other factors that cause stress.

Table 2 demonstrates the contents of total phenolic compounds, flavonoids and tannins obtained in the lettuce of conventional, organic and hydroponic cultivation system. According to the results, a statistically significant difference was observed between the lettuce of the three cultivation systems studied, the lettuce of the organic cultivation system presented the highest total phenolic content $\left(1845.69 \mathrm{mgEAGg}^{-1}\right)$ and flavonoids (1199.37 $\mathrm{mgEQg}^{-1}$ ) and the conventional cultivation of the highest tannin content $\left(1.17 \mathrm{mgECg}^{-1}\right)$.

Zambrano-Moreno et al. (2015) noted that lettuce from organic cultivation showed higher levels of phenolic compounds than the conventional system, with levels of $177.20 \mathrm{mgEAGg}^{-1}$ and $135.94 \mathrm{mgEAGg}^{-1}$, respectively, and these results are smaller when compared to those of this study (Table 2). However, the results corresponded with the association of the organic farming

Table 1. Proximate composition (\%) and Total Energetic Value (TEV) of lettuce of three different cropping systems. Teresina-PI, Brazil.

\begin{tabular}{|c|c|c|c|}
\hline \multirow{2}{*}{ Nutrients (\%)/ TEV (kcal/KJ/100 g) } & \multicolumn{3}{|c|}{ Cropping systems } \\
\hline & Conventional Mean \pm SD & Organic Mean \pm SD & Hydroponic Mean \pm SD \\
\hline Moinsture & $94.82 \pm 3.12^{\mathrm{a}}$ & $94.74 \pm 2.67^{\mathrm{a}}$ & $95.21 \pm 2.19^{\mathrm{a}}$ \\
\hline Ashes & $0.96 \pm 0.01^{\mathrm{a}}$ & $1.01 \pm 0.04^{\mathrm{a}}$ & $0.71 \pm 0.01^{\mathrm{c}}$ \\
\hline Lipids & $0.80 \pm 0.06^{\mathrm{a}}$ & $0.52 \pm 0.02^{\mathrm{b}}$ & $0.66 \pm 0.04^{c}$ \\
\hline Carbohydrates (difference method) & $1.97^{\mathrm{a}}$ & $1.86^{\mathrm{a}}$ & $2.09^{c}$ \\
\hline
\end{tabular}

Mean \pm standard deviation was obtained from triplicate measurements. Different letters overwritten in the columns, there is significant difference between means at the level of $\mathrm{p}<0.05$. Tukey test. SD: standard deviation.

Table 2. Phenolic content, flavonoid content, tannins content of lettuce of three different cropping systems. Teresina-PI, Brazil.

\begin{tabular}{lcrr}
\hline \multirow{2}{*}{ Bioactive compounds } & \multicolumn{3}{c}{ Cropping systems } \\
\cline { 2 - 4 } & Conventional Mean \pm SD & Organic Mean \pm SD & Hydroponic Mean \pm SD \\
\hline Total Phenolic content $\left(\mathrm{mgEAG}^{\mathrm{I}} \mathrm{g}^{-1}\right)$ & $965.36 \pm 20.87^{\mathrm{a}}$ & $1845.69 \pm 0.00^{\mathrm{b}}$ & $1522.02 \pm 0.00^{\mathrm{c}}$ \\
Flavonoid content $\left(\mathrm{mgEQ}^{\mathrm{II}} \mathrm{g}^{-1}\right)$ & $937.71 \pm 0.03^{\mathrm{a}}$ & $1199.37 \pm 0.03^{\mathrm{b}}$ & $965.09 \pm 0.01^{\mathrm{c}}$ \\
Tannins content $\left(\mathrm{mgEC}^{\mathrm{III}} \mathrm{g}^{-1}\right)$ & $1.17 \pm 0.00^{\mathrm{a}}$ & $0.21 \pm 1.66^{\mathrm{b}}$ & $0.21 \pm 3.31^{\mathrm{b}}$ \\
\hline
\end{tabular}

${ }^{\mathrm{I} E A G}$ : Equivalent of gallic acid; "IIEQ: Quercetin equivalent; ${ }^{\mathrm{II}} \mathrm{EC}$ : Equivalent of Catechin. Data are presented as mean of three replicates + standard deviation (SD). Equal letters overwritten between the columns did not present significant difference between the second means, Tukey averages test at the $\mathrm{p}<0.05$ level. 
system to present higher levels to the other cultivation systems, especially the conventional system. One of the explanations is due to the region (northeast of Brazil) of the analyzed lettuces, characterized by having a different climatic condition, among them the temperature that has a directly proportional relationship with the production of phenolic compounds by the vegetables. Where high temperatures raising the stress levels of the plant and the higher production of polyphenols.

Studies that are compared to foods obtained by conventional, organic and hydroponic cultivation systems demonstrate that organic fruits and vegetables have higher levels of phenolic compounds (Fontana et al., 2018; Zambrano-Moreno et al., 2015). Being observed the same results obtained in this study, where the lettuce of the organic cultivation system presented the highest content of phenolic compounds (Table 2).

Tiveron (2010) that determined the phenolic composition of vegetables (legumes and vegetables) consumed in Brazil, among them lettuce, obtained the highest result of the content of phenolic compounds for lettuce with $1690 \mathrm{mgEAGg}^{-1}$, a result similar to that verified In this study with the hydroponic cultivation system $\left(1522 \mathrm{mgEAGg}^{-1}\right)$.

There are several factors that can interfere with the content of phenolic compounds, among these are seasonal, temperature, water availability, atmospheric pollution, mechanical damage, attack of pathogens. These facts justify the differences in the content of phenolic compounds in the lettuce samples of different systems cultivating this study, since the agricultural practices adopted in each cultivation system influence their content (Fontana et al., 2018; Rodrigo-García et al., 2019; Salomão-Oliveira et al., 2018).

The content of flavonoids obtained for crisphead lettuce in this study were higher than in the study Zambrano-Moreno et al. (2015), which was 90.79 to $100.69 \mathrm{mgEQg}^{-1}$. Factors such as temperature change influence the flavonoid content, where it was observed that at higher temperatures the levels were also higher. It is observed that the analyzed samples were grown in the Northeast region, where it presents high temperatures, a higher flavonoids content was found.

Leafy green vegetable foods have high concentrations of flavonoids, which are mainly responsible for the antioxidant activity of the food. Thus, it is known that the organic and hydroponic cultivation systems in lettuce are characterized by having greener leaves, which also favors the greater purchase intention by consumers (Oliveira et al., 2013; Fontana et al., 2018; Salomão-Oliveira et al., 2018), when compared to those of the conventional system. In such a way that the content of phenolics and flavonoids found in this study, can be explained by the development of lettuces due to the type of cultivation system, valuing even more than in different environmental conditions, such systems are capable of providing a food with a higher content of bioactive compounds.

The content of tannins can vary according to climatic and geographical conditions, maturation, part collected, among others, and may present a varied chemical composition, being often little known. The analyzed lettuces showed small levels of tannins, being positive to contribute to the sensory aspects of the food making it tastier.
The antioxidant activity of the lettuce in the organic, hydroponic and conventional cultivation systems analyzed by the capture method of the radical DPPH, is exposed in Table 3, expressed in $\mu$ molTEACg ${ }^{-1}$. It was found that among the cultivation systems Studied, there was significant difference $(\mathrm{p}<0.05)$, in which the lettuce of the organic cultivation system was the one that presented greater capacity of reduction of the radical DPPH (4075.28 $\left.\mu_{\text {molTEACg }}{ }^{-1}\right)$, giving the same, greater antioxidant activity, followed by the lettuce of the Hydroponic and conventional cultivation, with contents of 3074.30 and $2136.88 \mu$ molTEACg $^{-1}$, respectively.

A possible justification for organic cultivation lettuce to obtain greater antioxidant activity among the others, was due to the higher content of total phenolic compounds (Table 2) thus contributing to greater inhibition capacity of the DPPH radical.

In the study of Tiveron (2010) which determined the antioxidant activity of plant foods (legumes and vegetables) consumed in Brazil, it was obtained for lettuce $54.9 \mu$ molTEACg $^{-1}$, this lower content, to the verified in this study. Zambrano-Moreno et al. (2015) that determined antioxidant activity in organic and conventional greenery, demonstrated greater activity of organic vegetables, among them lettuce, in reducing the DPPH radical when compared with conventional system with the results obtained in this research. The same result was observed by Rodrigo-García et al. (2019) in the hydroponic cultivation system.

Observing the data presented in the literature, where vegetables, such as lettuce, which received higher concentrations of nitrogen had leaves with a more intense green color (Rodrigo-García et al., 2019; Sapkota et al., 2019), greater antioxidant activity (Zambrano-Moreno et al., 2015). In addition to having increased concentrations in the contents of phenolics and flavonoids, in organic and hydroponic cultivation systems compared to the conventional system. Thus, the lettuce of the organic cultivation system also presented higher protein content (Table 1) and phenolic compounds (Table 2), these two factors contributing to its greatest antioxidant activity (Table 3).

The antioxidant activity is dependent on the species, geographical origin, agricultural practices employed as well as the cultivation system, justifying the variations in the results obtained in the present study with the literature. With sample factors studied as high temperatures, protein content (nitrogen content) and higher levels of phenolic compounds, these contribute to greater antioxidant activity.

On the other hand, some of the variables such as nitrogen content can be controlled by the cultivation systems, increasing

Table 3. Antioxidant capacity by the radical capture method in lettuce from three cropping systems. Teresina-PI, Brazil.

\begin{tabular}{cc}
\hline Cropping systems & DPPH $\left(\mu\right.$ molTEAC $\left.{ }^{\star} \mathrm{g}^{-1}\right)$ \\
\cline { 2 - 2 } & Mean \pm SD \\
\hline Conventional & $2136.88 \pm 50.81^{\mathrm{a}}$ \\
Organic & $4075.28 \pm 50.84^{\mathrm{b}}$ \\
Hydroponic & $3074.30 \pm 50.79^{\mathrm{c}}$ \\
\hline
\end{tabular}

${ }^{*}$ TEAC $=$ Trolox Equivalent Antioxidant Capacity. Data are presented as mean of three replicates + standard deviation (SD). Equal letters overwritten between the lines did not present significant difference between the second means, Tukey's mean test at the $\mathrm{p}<0.05$ level. 
the concentrations of phenolic compounds and nutrients present in the lettuce, especially the flavonoids, which can make the appearance of the vegetables more attractive, both in the cultivation system. organic and conventional farming system.

\section{Conclusions}

The curly lettuces presented good moisture and ash content in all analyzed cultivation systems. The lettuce of the conventional cultivation system presented greater content of lipids, whereas the organic cultivation presented greater protein content and the hydroponic cultivation increased carbohydrate content. The Total Energy Value (TEV) was greater to those observed in studies that determined the composition of the lettuce.

The crisphead lettuces from the hydroponic and organic cultivation system had a higher total phenolic content and higher antioxidant activity compared to the conventional cultivation system. These results highlight the findings in the literature and allow a broader look at the benefits that these cultivation systems can provide for health and even the acceptance of lettuce for consumption.

\section{References}

Association of Official Analytical Chemists - AOAC. (2005). Official methods of analysis of the Association of Official Analytical Chemists (18th ed.). Arlington: AOAC.

Atwater, W. O., \& Woods, C. D. (1896). The chemical composition of american food materials (Bulletin, No. 28). Washington: U. S. Department of Agriculture, Office of Experiment Stations.

Blasa, M., Candiracci, M., Accorsi, A., Piacentini, M. P., Albertini, M. C., \& Piatti, E. (2006). Raw Millefiori honey is packed full of antioxidants. Food Chemistry, 97(2), 217-222. http://dx.doi. org/10.1016/j.foodchem.2005.03.039.

Brand-Williams, W., Cuvelier, M. E., \& Berset, C. (1995). Use of a free radical method to evaluate antioxidant activity. LebensmittelWissenschaft + Technologie, 28(1), 25-30. http://dx.doi.org/10.1016/ S0023-6438(95)80008-5.

Brasil. (2017). Pesquisa de Vigilância de Fatores de Risco e Proteção para Doenças Crônicas por Inquérito Telefônico (VIGITEL). Brasília: Ministério da Saúde.

Campos, F. V., Oliveira, J. A., Pereira, M. G., \& Farnese, F. S. (2019). Nitric oxide and phytohormone interactions in the response of Lactuca sativa to salinity stress. Planta, 250(5), 1475-1489. http:// dx.doi.org/10.1007/s00425-019-03236-w. PMid:31327043.

Chiconato, D. A., Galbiatti, J. A., Maldonado, W., Franco, C. F., \& Caramelo, A. D. (2014). Bovine biofertilizer and irrigation layers on lettuce development and leaf chlorophyll. Comunicata Scientiae, 5(2), 140-147.

El-Nakhel, C., Petropoulos, S. A., Pannico, A., Kyriacou, M. C., Giordano, M., Colla, G., Troise, A. D., Vitaglione, P., De Pascale, S., \& Rouphael, Y. (2019). The bioactive profile of lettuce produced in a closed soilless system as configured by combinatorial effects of genotype and macrocation supply composition. Food Chemistry, 309, 125713. http://dx.doi.org/10.1016/j.foodchem.2019.125713. PMid:31708345.

Fernandes, A. A., Martinez, H. E. P., Pereira, P. R. G., \& Fonseca, M. C. M. (2002). Produtividade, acúmulo de nitrato e estado nutricional de cultivares de alface, em hidroponia, em função de fontes de nutrientes. Horticultura Brasileira, 20(2), 195-200. http://dx.doi. org/10.1590/S0102-05362002000200016.

Fontana, L., Rossi, C. A., Hubinger, S. Z., Ferreira, M. D., Spoto, M. H. F., Sala, F. C., \& Verruma-Bernardi, M. R. (2018). Physicochemical characterization and sensory evaluation of lettuce cultivated in three growing systems. Horticultura Brasileira, 36(1), 20-26. http://dx.doi. org/10.1590/s0102-053620180104.

Food and Agriculture Organization of the United Nations - FAO. (2019). FAOSTAT. Rome: FAO. Retrieved from http://www.fao. org/faostat/en/\#data/QC/

Gontijo, L. N., Silva, C. O., Stort, L. G., Duarte, R. M. T., Betanho, C., \& Tassi, E. M. M. (2017). Nutritional composition of vegetables grown in organic and conventional cultivation systems in Uberlndia, MG. African Journal of Agricultural Research, 12(21), 1848-1851. http:// dx.doi.org/10.5897/AJAR2016.11886.

Hilbe, J. M., \& Robinson, A. P. (2013). Methods of statistical model estimation. Boca Raton: Chapman \& Hall.

Kashyap, P., Mishra, D., \& Meena, V. S. (2017). Organic vegetables. In B. Gangwar \& N. K. Jat (Eds.), Towards organic agriculture (pp. 257-279). New Delhi: Today \& Tomorrow's Printers and Publishers.

Ketnawa, S., Suwannachot, J., \& Ogawa, Y. (2020). In vitro gastrointestinal digestion of crisphead lettuce: changes in bioactive compounds and antioxidant potential. Food Chemistry, 311, 125885. http://dx.doi. org/10.1016/j.foodchem.2019.125885. PMid:31780224.

Kim, D., Jeong, S. W., \& Lee, C. Y. (2003). Antioxidant capacity of phenolic phytochemicals from various cultivars of plums. Food Chemistry, 81(3), 321-326. http://dx.doi.org/10.1016/S0308-8146(02)00423-5.

Oliveira, D. C. R., Leal, P. A. M., Honório, S. L., \& Soares, E. K. B.. (2013). Sensory quality attributes of lettuce obtained using different harvesting performance systems. Food Science and Technology, 33(2), 239-244. http://dx.doi.org/10.1590/S0101-20612013005000031.

Oliveira, J. J., Dalmazo, G. O., Morselli, T. B. G. A., Oliveira, V. F. S., Corrêa, L. B., Nora, L., \& Corrêa, E. K. (2018). Composted slaughterhouse sludge as a substitute for chemical fertilizers in the cultures of lettuce (Lactuca sativa L. ) and radish (Raphanus sativus L. ). Food Science and Technology, 38(1), 91-97. http://dx.doi. org/10.1590/1678-457x.00717.

Patella, A., Palumbo, F., Galla, G., \& Barcaccia, G. (2019). The molecular determination of hybridity and homozygosity estimates in breeding populations of lettuce (Lactuca sativa L.). Genes, 10(11), 1-12. http:// dx.doi.org/10.3390/genes10110916. PMid:31717592.

Pei, R., Liu, X., \& Bolling, B. (2020). Flavonoids and gut health. Current Opinion in Biotechnology, 61, 153-159. http://dx.doi.org/10.1016/j. copbio.2019.12.018. PMid:31954357.

Price, M. L., Van Scoyoc, S., \& Butler, L. G. (1978). A critical evaluation of the vanillin reaction as an assay for tannin in sorghum grain. Journal of Agricultural and Food Chemistry, 26(5), 1214-1218. http:// dx.doi.org/10.1021/jf60219a031.

Rodrigo-García, J., Navarrete-Laborde, B. A., Rosa, L. A., AlvarezParrilla, E., \& Núñez-Gastélum, J. A. (2019). Effect of Harpin protein as an elicitor on the content of phenolic compounds and antioxidant capacity in two hydroponically grown lettuce (Lactuca sativa L. ) varieties. Food Science and Technology, 39(1), 72-77. http://dx.doi. org/10.1590/fst.20417.

Rufino, M. S. M., Alves, R. E., Pérex-Jiménez, J., Saura Calixto, F., Brito, E. S., \& Mancini-Filho, J. (2010). Bioactive compounds and antioxidant capacities of 18 non-traditional tropical fruits from Brazil. Food Chemistry, 121(4), 996-1002. http://dx.doi.org/10.1016/j. foodchem.2010.01.037. 
Salomão-Oliveira, A., Lima, E. S., Marinho, H. A., \& Carvalho, R. P. (2018). Benefits and effectiveness of using Paullinia cupana: a review article. Journal of Food and Nutrition Research, 6(8), 497-503. http:// dx.doi.org/10.12691/jfnr-6-8-2.

Sapkota, S., Sapkota, S., \& Liu, Z. (2019). Effects of nutrient composition and lettuce cultivar on crop production in hydroponic culture. Horticulturae, 5(4), 72. http://dx.doi.org/10.3390/horticulturae5040072.

Shahidi, F., Janitha, P. K., \& Wanasundara, P. D. (1992). Phenolic antioxidants. Critical Reviews in Food Science and Nutrition, 32(1), 67-103. http://dx.doi.org/10.1080/10408399209527581. PMid:1290586.

Singleton, V. I., \& Rossi, J. (1965). Colorimetry of total phenolic with phosphomolybdic-phosphotungstic acid agents. American Journal of Enology and Viticulture, 16, 144-158.

Souza, A. V., Vieira, M. R. S., \& Putti, F. F. (2018). Correlações entre compostos fenólicos e atividade antioxidante em casca e polpa de variedades de uva de mesa. Brazilian Journal of Food Technology, 21(0). http://dx.doi.org/10.1590/1981-6723.10317.
Souza, P. F., Borghezan, M., Zappelini, J., Carvalho, L. R., Ree, J., BarcelosOliveira, J. L., \& Pescador, R. (2019). Physiological differences of 'crocantela' lettuce cultivated in conventional and hydroponic systems. Horticultura Brasileira, 37(1), 101-105. http://dx.doi.org/10.1590/ s0102-053620190116.

Tiveron, A. P. (2010). Atividade antioxidante e composição fenólica de legumes e verduras consumidos no Brasil (Dissertação de mestrado). Universidade de São Paulo, Piracicaba.

Zambrano-Moreno, E. L., Chávez-Jáuregui, R. N., Plaza, M. D. L., \& Wessel-Beaver, L. (2015). Phenolic content and antioxidant capacity in organically and conventionally grown eggplant (Solanum melongena) fruits following thermal processing. Food Science and Technology, 35(3), 414-420. http://dx.doi.org/10.1590/1678-457X.6656.

Watt, B., \& Merrill, A. L. (1963). Composition of foods: raw, processed, Prepared (Agricultural Handbook No. 8). Washington, DC: Consumer and Food Economics Research Division / Agricultural Research Service. 